\title{
A MAGYAR ÉLELMISZERGAZDASÁG JELLEMZŐI ÉS KIHÍVÁSAI A XXI. SZÁZADBAN
}

\author{
Panyor Ágota
}

\begin{abstract}
Absztrakt: A magyar élelmiszergazdaság alakulása kerül áttekintésre a rendszerváltástól az Uniós csatlakozásig, majd az Uniós csatlakozást követỏen napjainkig. Részletesen kitérek az élelmiszerek fogyasztási szerkezetének alakulására és az ebből következő piaci kihívásokra. Továbbá a magyar élelmiszergazdaság problémáit és azok megoldási lehetöségeit vizsgálom az élelmiszertermelés és élelmiszer kereskedelem vonatkozásában.
\end{abstract}

Abstract: The change of the Hungarian food economy will be reviewed from the regime change to the accession to the EU and after the accession, to the present. I will detail the changes of the food consumption structure and the consequent market challenges. Furthermore, I examine the problems of the Hungarian food economy and their solutions to food production and food trade.

Kulcsszavak: élelmiszergazdaság, fogyasztási szerkezet, piaci kihívások

Keywords: food economy, consumption structure, market challenges

\section{Bevezetés}

Az élelmiszergazdaság egy nemzetgazdaságon belül kulcsfontosságú szerepet tölt be. Az élelmiszergazdasághoz szorosan kapcsolódó területek: a mezőgazdaság, az élelmiszeripar és az élelmiszer kereskedelem. Indokolt, hogy ezen területeket együttesen vizsgáljuk, mivel szoros kapcsolatban vannak egymással és vertikális összefonódás jellemzi őket, tehát egységes rendszert alkotnak. Hazánkban az 1970es években honosodott meg az élelmiszergazdaság fogalma, miszerint olyan szemléletet és vizsgálati módszertant alkalmaz, amely az élelmiszertermelés kérdéskörét a legszélesebb nemzetgazdasági vertikumban tárgyalja. Valamint e fogalom alá sorolja a termelőeszközök előállításával, forgalmazásával, a mezőgazdasági és élelmiszeripari termeléssel, a felvásárló kereskedelemmel foglalkozó szervezeteket is. Az élelmiszergazdaság fogalmának szinonimája az angol szakirodalomban az ,agribusiness” kifejezés.

\section{A magyar élelmiszergazdaság jellemzői a rendszerváltástól az Uniós csatlakozásig}

Az élelmiszeripari vállalatok privatizációja 1990 őszén kezdődött és a '90-es évek közepére jellemzően be is fejeződött (minden más nemzetgazdasági ágazatot megelözve). Az 1990-es évek elején az élelmiszeripari vállalkozások vagyonának legalább részleges megmentésére csak a külföldi tőke bevonásával mutatkozott lehetőség. A magyar élelmiszeripar magánosításának eredményeként jelentősen javult a magyar élelmiszeripari termékek minősége, biztonságossága és színvonalasabb lett a hazai kínálat. Az 1990-es évek közepétől ún. másodlagos privatizációs hullám indult meg, melynek eredménye az volt, hogy a hazai élelmiszeriparban erős differenciálódás és tulajdonosi koncentráció alakult ki. A külföldi tulajdonban lévő vállalatok részesedése a hazai élelmiszerpiacból (52-55\%) 
és az exportból (75-80\%) szembetünően növekedett, ezzel ellentétben a hazai kis- és középüzemek drámai mértékü piacvesztést könyvelhettek el maguknak (Raskó, 1999).

A rendszerváltás és a privatizáció az élelmiszer-kereskedelemben is mérvadó változásokat eredményezett. A '90-es évek elején az élelmiszer-kereskedelem meglehetősen vonzónak bizonyult a külföldi befektetők számára. Számos nemzetközi üzletlánc kezdte meg müködését hazánkban, akár régi üzleteket helyreállítva, akár zöldmezős beruházás révén. A külföldiek mellett magyar tulajdonú üzletláncok is alakultak, amelyek közül néhány jelentösen gyors ütemben fejlödött. Mindezek ellenére a magyar kereskedelmi vállalkozások túlnyomó része tőkeszegény kis-és középvállalkozásnak számított (www.szie.hu/2012).

A magyar élelmiszeripar termelése az 1990-es évek első harmadában megvalósult fokozatos csökkenést követően, a termelés 1998-tól újbóli növekedést ért el, de még 2002-ben sem sikerült elérnie az 1989. évi eredményt. A magyar élelmiszeripar 1996-2004 között 7 százalékpontot veszített részesedéséből a nemzetgazdasági ágazatok között. Sőt az élelmiszeripar exportorientáltsága is visszaesőben volt, a nemzetgazdasági exportból való részesedése felére csökkent az említett időszakban. Összességében az élelmiszeripar gyenge teljesítménye a kapacitásfeleslegböl, az alacsony tőkeellátottságból, az állandóan változó tulajdonosi körből, a pénzügyi befektetők nem egyszeri csődöt okozó magatartásából, a csekély termelékenységből és az egyes ágazatokban az alacsony koncentrációból fakadó piaci erők hatástalanságából volt eredeztethető. Mindezek mellett szerepet játszott az import növekedése és a kiskereskedelmi láncok árleszorító magatartása is (Juhász et. al., 2006).

A rendszerváltás éveiben a birtokstruktúra is jelentős változásokon ment keresztül. A föld tulajdonosi szerkezete is lényegesen megváltozott, hiszen 1990-ben a mezőgazdasági terület $35 \%$-a volt magán-, 34\%-a állami- és $31 \%$-a szövetkezeti tulajdonban. Míg 2003-ra a magán tulajdon vált dominálóvá (83\%-os részesedéssel), az állami tulajdon 10\%-ra és a szövetkezeti tulajdon 3\%-ra esett vissza. A magánvállalkozások részarányának növekedése mellett erőteljes terület szétaprózódás ment végbe (Potori-Udovecz (szerk.) et. al., 2004).

\section{A magyar élelmiszergazdaság jellemzése 2004. után}

Magyarország 2004. május 1-én csatlakozott az Európai Unióhoz. A magyar élelmiszeripart érettnek találták a csatlakozásra és úgy vélték, hogy 2004 után nyertes ágazat lehet hazánkban. Ahhoz, hogy a magyar élelmiszeripar a hazai piacon és az uniós országokban megállja a helyét a versenyben, ki tudja használni az új piaci lehetőségeket, és ne kelljen lemondania a hazai fogyasztás igényes részéröl, alapvető fontosságú a mezőgazdasággal fenntartott, megbízható kapcsolatrendszer és ez által egy igényes mezőgazdasági termelői kultúra gyors kiterjesztése. Ez a cél természetesen csak megfelelő és összehangolt állami szerepvállalás mellett érhető el, olyan intézményrendszert és intézményi kultúrát szükséges kialakítani, amilyenre az EU-beli élelmiszeripari versenytársak is támaszkodnak (www.penzugykutato.hu, 2012). 
Azonban számos, pozitív előrejelzés a valóságban nem ment végbe. $\mathrm{Az}$ élelmiszeripar az EU csatlakozást követően fokozatosan veszített a lendületéből. Felerősödtek a negatív tendenciák, az élelmiszertermelés és a belföldi értékesítés visszaeséséről, az élelmiszerfogyasztás stagnálásáról, a külföldi termékek hazai piacon történő térnyeréséröl, az iparág árbevétel-arányos eredményének erodálásáról, növekvő és kielégítetlen beruházásigényéről, az élelmiszeripari vállalati csődök felgyorsulásáról, végeredményben az élelmiszeripar nemzetgazdasági jelentőségének csökkenéséről szóltak a nyilatkozatok (Kapronczai, 2010).

Az uniós csatlakozást követően nagymennyiségü, alacsony minőségü és olcsó feldolgozott élelmiszer érkezett az EU tagországaiból, elárasztva a belföldi piacokat, $s$ egyben kiszorítva onnan a kevésbé versenyképes hazai élelmiszereket. Ennek hatására az élelmiszeripar bruttó termelési értéke jóval visszaesett, sőt a belföldi értékesítés mértéke is enyhülö tendenciát mutatott. A magyar élelmiszergyártóknak további problémával kellett szembenézniük az áruházláncok árleszorító politikája miatt. Ezen problémák orvoslására jelent meg az új kereskedelmi törvény, amely a beszerzési ár alatti eladásokat hivatott szabályozni, valamint az élelmiszerbiztonsági ellenörzések kapcsán kiválogatja a gyenge minöségü külföldi élelmiszereket és a szabálytalanságok elkövetésekor megfelelő szankciókat léptet életbe.

A magyar mezőgazdaság teljesítménye is romlott, ezen gazdasági visszaesés a ráfordítások és a teljesítmények abszolút értékében is megnyilvánult. A gabonafélék termesztését kiemelve, megállapítható, hogy alapvetően nem változott a csatlakozás után a gabona-szántóterületének aránya, a gabonatermesztők számára a legnagyobb biztonságot az intervenciós rendszer biztosította. Az állattenyésztés részaránya a mezögazdasági termékek bruttó kibocsátásából folyamatosan csökkent. A fontosabb állattenyésztési ágazatok közül arányaiban a legnagyobb hanyatlást a sertéságazat szenvedte el, hiszen 2004 után 30\%-ot meghaladó csökkenés történt. Az agrárgazdaság külkereskedelmi aktívuma 2006-2008 között megduplázódott (a feldolgozatlan formában értékesített mezőgazdasági termékek kivitelének több mint 1 milliárd euróval történő növekedéséből adódik). 2004-2009 között a behozatal folyamatában, évente 0,3-0,6 milliárd euróval emelkedett. A kivitel 2005. évtől stabilan növekedett (Oláh, 2009).

\section{A 2008. évi gazdasági válság hatásai a magyar élelmiszergazdaságra}

Az Amerikai Egyesült Államokban 2007-ben jelzálogpiaci válság ütötte fel a fejét, amely pénzügyi válsággá nőtte ki magát és 2008-ra az egész világot megrengette. A XXI. század elején kialakult válság olyan mértékü volt, amelyre az 1929/30-as nagy gazdasági világválság óta nem volt példa. A pénzügyi válságon belül vegyük szemügyre az élelmiszergazdaság tendenciáit érintő eseményeket. Wagner (2009) szerint az utóbbi húsz évben alig történt változás az élelmiszergazdaság világpiaci áraiban, azonban 2007-ben valóságos árrobbanás alakult ki a mezőgazdasági termékek esetében, melyet 2008-ban hasonló nagyságú áresés kísért. Az élelmiszerár-sokkot kiváltó tényezőket három csoportba sorolták Popp és szerzötársai (2008): 
3. Mezőgazdasági termelést és kereskedelmet befolyásoló ökológiai és biológiai természetủ tényezők,

4. Makrogazdasági környezetre ható tényezők (népesség és fogyasztói jövedelmek növekedése, kőolaj világpiaci árának drasztikus emelkedése stb.),

5. Agrár- és kereskedelempolitikai tényezők (kereskedelemkorlátozó intézkedések, reformok, bioüzemanyag-gyártás ösztönzése stb.).

A magyar agrárgazdaság részaránya a nemzetgazdaságon belül is jelentős mértékben csökkent a válság után. Az élelmiszeripar részarányát tekintve 2009-re a nemzetgazdasági GDP-böl a 2002. évinek mintegy kétharmadára esett vissza (alig haladta meg a 2\%-ot). Ezen tény mögött a hazai élelmiszeripar helyzetének romló tendenciája áll. A mezőgazdaság és az élelmiszeripar együttesen a nemzetgazdaság bruttó hazai termelésének 5-6\%-át adta 2009-ben. A foglalkoztatottságot figyelembe véve a mezőgazdaságban következett be a legjelentősebb visszaesés. De az élelmiszeriparban is hasonló folyamatok zajlottak le, mivel még 2002-ben a foglalkoztatottak 4,2\%-át alkalmazták az élelmiszeriparban, addig 2009-re 3,5\%-ra csökkent ez az érték. Az élelmiszeripari kibocsátás 2002 és 2009 között évente 27\%-os visszaesésnek volt kitéve, a termelés volumene a meghatározó szakágazatok többségében csökkent.

$\mathrm{Az}$ élelmiszeripari termékek importjának erőteljes növekedését jól mutatják a 2002. és a 2009. évi adatok eltérései. 2002-ben 844 millió euró értékủ import élelmiszer került hazánkba, addig 2009-re már 2.778 millió euró értéket tett ki, amely több mint háromszoros növekedést jelentett. Mind emellett a hazai élelmiszerfogyasztás csak szerény mértékben ért el emelkedést. Az élelmiszeripar tehát a hazai piacon szenvedte el a legnagyobb veszteségeit.

$\mathrm{Az}$ élelmiszer-feldolgozás hozzáadott értéke változatlan áron 2004 és 2014 között 14,3\%-kal csökkent, míg ugyanezen időszakban Ausztriában 0,8\%-kal, Hollandiában 0,5\%-kal, Csehországban 8,5\%-kal, Szlovákiában 15,9\%-kal növekedett.

\section{A hazai élelmiszergazdaság jellemzői napjainkban}

Magyarország belső piacát továbbra is a gyenge fizetőképes kereslet jellemzi. A háztartások vásárlóerővel korrigált egy főre eső jövedelme és a háztartások egy före jutó végső fogyasztási kiadásai is nagy lemaradást mutatnak az EU-átlaghoz képest. Az élelmiszerekre és nem alkoholos italokra fordított magyarországi kiadás szintje az egyik legalacsonyabb a tagországok közül. A hazai élelmiszerkereslet gyengesége mellett a fogyasztók erős árérzékenysége kedvezőtlenül befolyásolja a magyarországi élelmiszergyártók jövedelmezőségét abban az esetben, ha csak a belföldi piacra alapoznak.

$\mathrm{Az}$ alacsony magyarországi fizetőképes kereslet ellenére az elmúlt években egyre inkább találkozunk a minőségi termelésre alapozott sikeres belső piaci érékesítésre koncentráló stratégiákkal is, föként a kisebb méretü cégek között. Ezek a vállalatok azt a szúk réteget (niche) célozzák meg, amelyik még hajlandó magasabb árat fizetni a magas minőségért, termékeiket alternatív értékesítési csatornákon 
keresztül értékesítik. A minőségi termelés viszont egyfajta növekedési korlátot is jelent ezen cégek számára, hiszen amennyiben nagyobb volumenben gyártanának, be kellene lépniük a modern kiskereskedelmi csatornákban, ahol számukra is elindulna az árverseny, ami komoly kihívást jelentene, mert kis méretük és a fogyasztói igények kielégítésére, minőségi termelésre való törekvéseik nyomán túl széles termékválasztékuk miatt egyelőre hatékonysági problémákkal küzdenek.

A fogyasztók megnyerésének egyik fontos eszköze lehet a folyamatos leginkább termékhez kapcsolódó - innováció. A lehetőségek ellenére azonban ritkán és kismértékben találkozhatunk innovációval, amit részben indokol az alacsony jövedelmezöség, vagyis, hogy nem jut forrás a fejlesztésekre, de a másik okként felmerül a belső piac mérete is, ami elég korlátozott, így azon belül egy speciális szegmens még kisebb keresletet jelent (Kürthy et. al., 2016).

A hagyományosan igényes európai piacok közelsége és a számos Európán kívüli országban a minőségi európai termékek iránti kereslet növekedése lehetőséget teremt prémium minőségü termékek növekvő mértékủ értékesítésére. Ehhez jól müködő eredetvédelmi és minőségtanúsító rendszerekre van szükség, amelyek hitelesen támasztják alá termékeink minőségét, GMO-mentességét, termelésünk alacsony környezetterhelését, valamint adott esetben ökológiai gazdálkodásból való származását.

\section{6. Összegző gondolatok}

Magyarország a maga 5,4 millió hektár mezőgazdasági területével és a 2 millió hektár erdőterületével olyan élelmiszeripari potenciállal rendelkezik, amelyet messze nem használ ki. A hazai termelés és piac hatékonyabb szervezésével, a feldolgozottság növelésével a világban lévő keresletre való célirányos reagálással a magyar élelmiszergazdaságban a mostaninál $60 \%$-kal nagyobb termelési potenciál van.

Egyértelmüen megállapítható, hogy a magyarországi élelmiszeripar az európai uniós tagországokhoz történő összehasonlításban komoly lemaradással küzd. A hazai vállalkozások árbevétele, hozzáadott értéke és munkatermelékenysége elmarad az EU legjelentősebb élelmiszeriparával rendelkező tagországainak adataitól, de a velünk együtt csatlakozó Lengyelországhoz képest is hátrányban van. Az egy vállalkozásra jutó munkavállalók számát tekintve viszont a magyarországi értékek az átlagosnál magasabbak, ami elsősorban a technológiai lemaradásnak és a viszonylag olcsó munkaerőnek tulajdonítható.

A legtöbb élelmiszeripari vállalkozás számára a nyomott árakon való értékesítés kedvezőtlen pénzügyi helyzetet, forráshiányt eredményez, ami megakadályozza a technológiai fejlesztéseket, innovációt. Az elmaradó beruházások viszont tovább rontják a vállalatok hatékonyságát, versenyképességét, így a gyenge teljesítmény újratermeli önmagát.

A teljesítmény növelésében megkerülhetetlen szerepe van a tudástermelés és átadás intézményei, csatornái müködésének. A vállalkozások versenyképességének XXI. századi alapja a folyamatos innováció, az azt megalapozó kutatás-fejlesztési 
tevékenység és az innovációs eredmények hasznosítását lehetővé tevő képzett munkaerö.

$\mathrm{Az}$ integráció mértékének növekedése tovább javíthatná az élelmiszer feldolgozók helyzetét, mert akár az alapanyag minöségi paramétereit is befolyásolni tudnák. Az élelmiszeripar eredményességét meghatározza az alapanyag minősége, ára, ugyanakkor a mezőgazdasági termelök számára is előnyös, egyes termékek esetében létkérdés, hogy fö felvevőpiaca, az élelmiszeripar átvegye az általuk termelt árut és azt megfelelően finanszírozza.

A magyarországi élelmiszeripar fontos kitörési pontja lehet az export, hiszen a külpiacon kedvezöbb árak érhetők el, ami javíthatja a feldolgozók bevételeit és profitját. Az exportképesség javításához viszont innovatívabb áruszerkezetre, a célpiacok igényeinek jobb megismerésére, erősebb marketingtevékenységre lenne szükség.

Egyértelmüen látszik, hogy a szektor egyik legnagyobb problémája a forráshiány. Ennek enyhítésére a jelenlegi uniós támogatási periódusban az élelmiszer-feldolgozás fejlesztésére 300 milliárd forint áll rendelkezésre. A mikroés kisvállalkozások a Vidékfejlesztési Program forrásaiból 200 milliárd forintra, míg a közepes vállalkozások a GINOP forrásaiból 100 milliárd forintra pályázhatnak.

\section{Irodalomjegyzék}

Juhász A., Kartali J., Kőnig G., Orbánné Nagy M., Stauder M. (2006): Az élelmiszeripar strukturális átalakulása (1997-2005). Agrárgazdasági Kutató Intézet, Budapest.

Kapronczai I. (2003): A magyar agrárgazdaság a rendszerváltástól az Európai Unióig. Szaktudás Kiadó Ház, Budapest.

Kapronczai I. (2010): A magyar agrárgazdaság az adatok tükrében az EU csatlakozás után. Agrárgazdasági Kutató Intézet, Budapest.

Kürthy Gy., Dudás Gy., Felkai B. (szerk.) (2016): A magyarországi élelmiszeripar helyzete és jövöképe. Agrárgazdasági Kutató Intézet, Budapest.

Oláh E. (2009): A magyar mezógazdaság az EU csatlakozás hatása alatt - 2004-2009. Mezögazdasági Szövetkezők és Termelök Országos Szövetsége, Budapest.

Potori N., Udovecz G. (szerk.) (2004): Az EU csatlakozás várható hatásai a magyar mezögazdaságban 2006-ig. Agrárgazdasági Kutató Intézet, Budapest.

Raskó Gy. (1999): Az élelmiszeripar privatizációja Magyarországon. GJW-Consultatio, Budapest.

Wagner H. (szerk.) (2009): A válság hatása a magyar élelmiszergazdasági külkereskedelemre nemzetközi összehasonlitásban. Agrárgazdasági Kutató Intézet, Budapest.

<http://szie.hu/file/tti/archivum/Stauder_Marta_ertekezes.pdf >

<http://www.penzugykutato.hu/files/Mohacsi_cikk_01.pdf> 